\title{
Comparison of the Measurement of Long-Term Care Costs between China and Other Countries: A Systematic Review of the Last Decade
}

\author{
Qingjun Zeng ${ }^{1}$, Qingqing Wang ${ }^{2}$, Lu Zhang ${ }^{1}$ and Xiaocang $\mathrm{Xu}{ }^{1,3, *(1)}$ \\ 1 School of Economics, Chongqing Technology and Business University, Chongqing 400067, China; \\ zqj@ctbu.edu.cn (Q.Z.); melodyzl@163.com (L.Z.) \\ 2 Research Center for Economy of Upper Reaches of the Yangtse River, Chongqing Technology and Business \\ University, Chongqing 400067, China; wqq199412@163.com \\ 3 Department of Actuarial Studies \& Business Analytics, Macquarie University, Sydney 2109, Australia \\ * Correspondence: cangxiaoxu@ctbu.edu.cn
}

Received: 1 April 2020; Accepted: 27 April 2020; Published: 29 April 2020

\begin{abstract}
Background: The rapid aging of populations in some countries has led to a growing number of the disabled elderly, creating a huge need for Long-Term Care (LTC) and meeting its costs, which is a heavy economic burden on the families of the disabled elderly and governments. Therefore, the measurement of Long-Term Care (LTC) costs has become an important basis for the government to formulate Long-Term Care (LTC) policies, and academic research on Long-Term Care (LTC) costs is also in the process of continuous development and deepening. Methods: This is a systematic review that aims to examine the evidence published in the last decade (2010-2019) regarding the comparison of the measurement of Long-Term Care (LTC) costs between China and other countries. Results: Eighteen Chinese studies and 17 other countries' studies were included in this review. Most Chinese scholars estimated long-term care costs based on the degree of disability among the disabled elderly. However, the studies of European and American countries are more and more in-depth and comprehensive, and more detailed regarding the post-care cost of specific diseases, such as Parkinson's disease, Alzheimer's disease, and epilepsy. Conclusion: In future academic research, we should fully consider the human value of long-term care providers and further study the differences in the long-term care costs of different chronic diseases. In China's future policymaking, according to the experience of Germany, Sweden, and other countries, it may be an effective way to develop private long-term care insurance and realize the effective complementarity between private long-term care insurance and public long-term care insurance (LTCI).
\end{abstract}

Keywords: Long-Term Care (LTC); long-term care costs; disabled elderly; institutional care; home care

\section{Introduction}

The increasingly aging population has highlighted the urgency of the crisis in healthcare services for the elderly in China in recent years. According to World Population Prospects (2019), published by the Department of Economic and Social Affairs of United Nations (WPP2019), population aging is expected to increase rapidly (South Korea, 38.1\%; Japan, 37.7\%; Italy, 36.0\%; Germany, 30.0\%; and China, 26.1\%) by 2050 [1]. According to CSY (China Statistical Yearbook, 2019), the elderly population, aged 65 or above, reached 167 million in 2018, accounting for 11.9 percent of the total population. The ODR (old-age dependency ratio) climbed from $9.9 \%$ in 2000 to $16.8 \%$ in 2018 [2]. The average life expectancy in China is expected to reach 81.52 years in 2045-2050, which is close to the average of 83.43 years in developed countries (WPP2019). Among them, the number of disabled elderly due to chronic diseases [3], industrial or agricultural environmental pollution [4-7], accidental injuries, 
and natural aging is increasing sharply. Accordingly, the demand for LTC (Long-Term Care) services and its cost for the elderly are growing rapidly [8,9]. However, the provision of LTC (Long-Term Care) services such as policy formulation, operational models, and, especially, fund-raising lag far behind in China. As a result, the "Healthy China Strategy" has been proposed in the Report of the 19th National Congress of China.

Long-Term Care (LTC) refers to the various supportive personal and social services needed by people who are unable to take care of themselves for a long time. The existing definitions differ in the causes of incapacitation and the content of services, leading to the definition of LTC being somewhat vague. For instance, the World Health Organization (WHO) considers LTC to be "a system of care activities carried out by informal caregivers (family, friends or neighbors) and professionals (health and social services) to ensure that those who do not have full self-care capacity continue to enjoy a higher quality of life" [10]. The National Institute on Aging (NIA) indicates that "Long-term care involves a variety of services designed to meet a person's health or personal care needs during a short or long period of time. These services help people live as independently and safely as possible when they can no longer perform everyday activities on their own" [11]. The Health Insurance Association of America (HIAA) defines long-term care more broadly, stating that Long-Term Care (LTC) refers to "the care provided to people with chronic diseases, cognitive impairment, such as Alzheimer's disease or in a disabled state, that is, functional impairment, over a long period, which is made up of medical services, social services, home services, delivery services, or other support services" [12]. The difference between the HIAA's and NIA's definitions of "Long-Term Care (LTC)" is mainly reflected in three aspects. Firstly, the causes of service demand can include physical impairment and cognitive impairment. Secondly, the categories of services include both services involving the basic needs of the elderly, such as personal care and daily living, and extended and supportive services, such as healthcare and psychological care. Thirdly, the long-term care service forms can be either home nursing, that is, professional nursing personnel door-to-door service, or institutional nursing, that is-including in nursing homes-apartments for the elderly and other non-hospital professional nursing institutions for professional care. The definition of LTC by the HIAA has been widely used in academic discussions and the construction of the long-term care service system in China. Therefore, this paper makes some special definitions regarding LTC. Firstly, the target group of LTC service is only defined as the elderly, although children are not excluded from the definition of LTC. Secondly, the service categories of LTC include both daily care and healthcare after hospital care. Therefore, the differences between the postoperative care costs of different diseases can also constitute a discussion topic regarding the cost of LTC. Thirdly, the care forms of LTC consist of institutional care, community care, and home care. Even in recent years, some countries, such as China, have tried many innovations for the continuous improvement of long-term care service systems. For example, despite the name of "hospital", a "hospital for the elderly" is essentially a nursing institution similar in nature to nursing homes.

Long-term care systems have made great progress in developed countries since the 1960s. The LTC system in the UK is less dependent on public funds than in most other European countries. Its LTC services are financed by the National Health Service (NHS) and local governments [13]. In Japan, the Long-Term Care Insurance (LTCI) system was implemented in 2000 to cope with the growing costs of LTC. The applicant can decide the care level according to the amount available, and care beyond the fixed amount must be undertaken privately [14-16]. Sweden established a tax-based LTC system in the 1970s. Every city must provide help if the care demands of an individual cannot be satisfied [17]. In general, the scope of LTC and ability to meet the cost of providing it have been limited since a severe economic crisis in the 1990s. As a consequence, those countries will face substantial sustainability problems in providing LTC in the future. In China, the demand for LTC services has increased dramatically due to the aging population. The number of people aged 65 and above increased from 96 million in 2003 to about 150 million in 2018 [18]. However, the supply of LTC services, such as fund-raising, lags far behind. However, the government have introduced a series of policies and 
measures, such as the pilot of LTC insurance (LTCI), to establish a comprehensive LTC service system, in recent years.

The major difference between the U.S. and the other countries was the level of public funding, which was universally provided in Sweden, Denmark, and the Netherlands but only provided publicly by the U.S. to the disabled and indigent population or in a limited way to individuals after a hospital stay. The level of public funding is nearly $100 \%$ for Denmark, Sweden, and the Netherlands but only $72.9 \%$ in the United States [19]. As a result, the total U.S. long-term care spending paid out of pocket by patients and/or families in 2011 was $\$ 45.5$ billion [20]. Cash for care programs have been reported to be a part of all three European countries' LTC publicly provided programs, but this was not the case in U.S., which does not yet have a national model for these programs. Additionally, the U.S. LTC system lacked coverage for a large number of citizens compared to the systems of other OECD countries, where the major flaws of their LTC systems were the excessive costs and poor sustainability.

Compared with the systems in European and American countries, China's Long-Term Care (LTC) system started late and developed relatively slowly. For example, China's government-led public Long-Term Care Insurance (LTCI) has only been officially piloted in 15 cities, including Qingdao, Chongqing, and Shanghai, since 2016. Therefore, it is very important for China to learn from the valuable experience of Germany, Sweden, and other European and American countries that started to implement the Long-Term Care (LTC) system in the 1990s, as well as their relevant theoretical research. This review aims to examine the evidence published in the last decade (2010-2019) regarding the measurement of Long-Term Care (LTC) costs between China and other countries, and through the comparisons, to explore the academic space for further research, with a hope to provide policy recommendations for the construction of China's Long-Term Care (LTC) system.

\section{Materials and Methods}

This review was carried out to explore related studies published in the last decade (2010-2019) regarding the comparison of the measurement of Long-Term Care (LTC) costs between China and other countries.

\subsection{Literature Search Source}

Our review was carried out to show the measurement of Long-Term Care (LTC) costs in related studies. The databases mentioned in our review mainly were: Web of Science, Medline, SCOPUS, EBSCO, PubMed, and CNKI (China). The following combinations of terms were used, with the Boolean phrase "and/or", to maximize the scope and type of material referred in the search: "Long-Term Care cost" OR "LTC cost". The search was carried in Chinese and English. We also added a Chinese research database named VIP (China) to look for any studies that might be missing.

\subsection{Data Extraction Criteria}

Preliminary inclusion criteria: the selection criteria for publications were as follows: (1) studies on the measurement of Long-Term Care (LTC) costs; (2) research conducted in China and other countries, which should be strictly separated to facilitate subsequent analysis; and (3) research published from January 2010 to December 2019. Publications based on opinions or comments, editorials, and summaries of meetings were not included.

Exclusion criteria: these included articles reporting on the results of a qualitative study, quantitative analyses, surveys, feasibility studies, relationship measurements, satisfaction studies, "what-if" analyses, and data collection techniques. Publications based on opinions or comments, editorials, and summaries of meetings were not included. The results were initially extracted by one researcher and then cross-checked by another to ensure that all data had been screened and reviewed. If there was a difference of opinion between the two researchers, a third researcher was invited to express their opinion and finally reach an agreement. All publication information was exported to the Excel database via Endnote, and duplicate sections were removed. We followed some previous special definitions 
regarding LTC as described previously in this paper. Finally, 18 Chinese studies and 17 other countries' studies were retained for the review.

The information extracted from all the included publications was as follows: time frames, study methodology (design, purpose, participants, and tools), samples, and key conclusions. All the analysis results were analyzed in the following process (as shown in Figure 1).
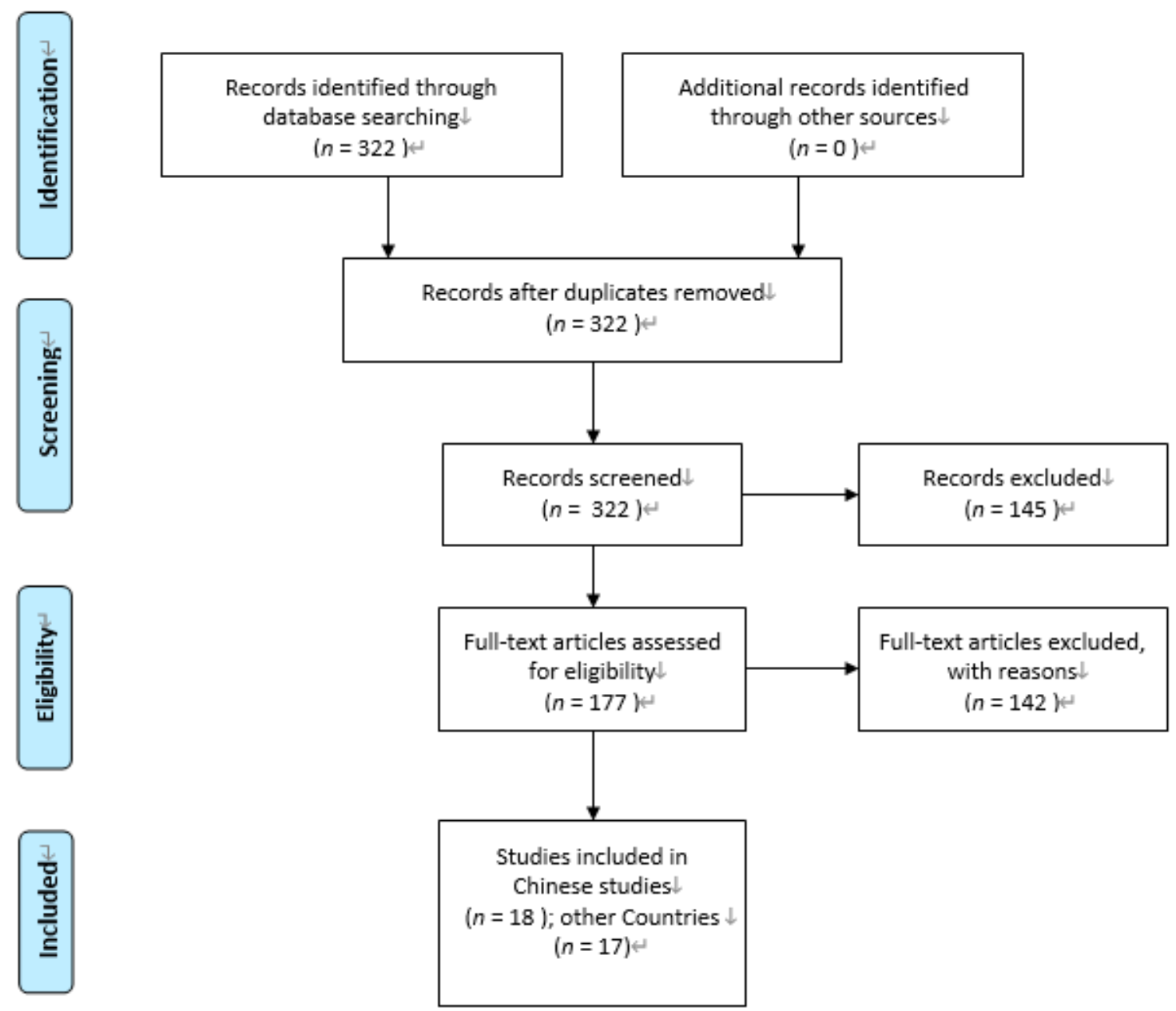

Figure 1. Flow diagram of study selection (PRISMA). Note: Moher D, Liberati A, Tetzlaff J, Altman DG, The PRISMA Group (2009) [21].

\subsection{Quality Assessment}

Study quality was independently assessed by the two researchers using the Risk of Bias Assessment Tool for Non-Randomized Studies (RoBANS) [22]. The criteria included the selection of participants, confounding variables, intervention measurements, the blinding of outcome assessments, the incompleteness of outcome data, and selective outcome reporting. Each criterion was evaluated as "low risk of bias", "high risk of bias", or "unclear". In cases of disagreement, each case was discussed with a third researcher. The quality of the included studies is summarized in Table 1. 
Table 1. Quality of studies.

\begin{tabular}{|c|c|c|c|c|c|c|}
\hline Risk of Bias & $\begin{array}{l}\text { Selection of } \\
\text { Participants }\end{array}$ & $\begin{array}{l}\text { Confounding } \\
\text { Variables }\end{array}$ & $\begin{array}{l}\text { Intervention } \\
\text { Measurement }\end{array}$ & $\begin{array}{l}\text { Blinding of } \\
\text { Outcome } \\
\text { Assessment }\end{array}$ & $\begin{array}{l}\text { Incomplete } \\
\text { Outcome } \\
\text { Data }\end{array}$ & $\begin{array}{l}\text { Selective } \\
\text { Outcome } \\
\text { Reporting }\end{array}$ \\
\hline Jin et al. [23], 2010 & $\bullet$ & $\Delta$ & $\bullet$ & $\bullet$ & * & $\bullet$ \\
\hline $\mathrm{Lu}[24], 2013$ & $\bullet$ & $\Delta$ & $\Delta$ & $\bullet$ & $\bullet$ & $\bullet$ \\
\hline Feng et al. [25], 2013 & $\bullet$ & $\Delta$ & $\bullet$ & $\bullet$ & $\bullet$ & $\bullet$ \\
\hline $\mathrm{Hu}[26], 2015$ & $\Delta$ & $\bullet$ & ※ & $\bullet$ & $\Delta$ & $\Delta$ \\
\hline Yuan [27], 2018 & $\bullet$ & $\Delta$ & * & $\bullet$ & * & $\bullet$ \\
\hline Liu \& Zhong [28], 2018 & $\bullet$ & $\Delta$ & * & $\bullet$ & $\bullet$ & $\Delta$ \\
\hline Xu et al. [29], 2019 & $\bullet$ & $\bullet$ & $\Delta$ & $\bullet$ & $\bullet$ & $\bullet$ \\
\hline Fengyue\&Junko [30], 2018 & $\bullet$ & ※ & ※ & $\bullet$ & * & $\bullet$ \\
\hline Yu et al. [31], 2015 & $\bullet$ & $\Delta$ & ж & $\bullet$ & $\Delta$ & * \\
\hline Fan et al. [32], 2016 & $\bullet$ & $\Delta$ & * & $\bullet$ & $\bullet$ & $\bullet$ \\
\hline Qun [33], 2013 & $\Delta$ & $\Delta$ & $\bullet$ & $\bullet$ & $\bullet$ & $\bullet$ \\
\hline Li et al. [34], 2018 & $\bullet$ & $\Delta$ & * & $\bullet$ & * & $\bullet$ \\
\hline Jin, Li, et al. [35], 2018 & * & $\Delta$ & $\bullet$ & $\bullet$ & * & * \\
\hline Yang et al. [36], 2016 & $\bullet$ & $\Delta$ & $\bullet$ & $\bullet$ & $\bullet$ & $\bullet$ \\
\hline Lu et al. [37], 2017 & $\bullet$ & $\bullet$ & * & $\bullet$ & $\bullet$ & $\bullet$ \\
\hline Huang et al. [38], 2012 & $\bullet$ & $\Delta$ & * & $\bullet$ & $\Delta$ & $\bullet$ \\
\hline Song et al. [39], 2016 & $\bullet$ & $\Delta$ & $\bullet$ & $\bullet$ & $\bullet$ & $\bullet$ \\
\hline Fen et al. [40], 2017 & $\bullet$ & $\Delta$ & * & $\bullet$ & $\bullet$ & * \\
\hline Ryan Greysen [41], 2017 & $\bullet$ & $\Delta$ & ※ & $\bullet$ & $\bullet$ & $\Delta$ \\
\hline Lagergren et al. [42], 2018 & $\bullet$ & $\bullet$ & ※ & $\bullet$ & * & $\bullet$ \\
\hline Sharada et al. [43], 2018 & $\bullet$ & $\Delta$ & $\bullet$ & $\bullet$ & $\Delta$ & $\bullet$ \\
\hline Larissa S et al. [44], 2012 & $\bullet$ & $\Delta$ & $\bullet$ & $\bullet$ & * & $\bullet$ \\
\hline Mitsuhiro S et al. [45], 2018 & $\bullet$ & $\bullet$ & ※ & $\bullet$ & $\bullet$ & $\bullet$ \\
\hline Hajime T et al. [46], 2019 & * & $\Delta$ & $\Delta$ & $\bullet$ & * & $\Delta$ \\
\hline Greg A et al. [47], 2015 & $\bullet$ & * & ※ & $\bullet$ & $\bullet$ & $\bullet$ \\
\hline Ramon L et al. [48], 2018 & $\bullet$ & $\bullet$ & ※ & $\bullet$ & $\bullet$ & $\bullet$ \\
\hline Julieta et al. [49], 2016 & $\bullet$ & $\Delta$ & ※ & $\bullet$ & $\bullet$ & $\bullet$ \\
\hline Saori et al. [50], 2017 & $\bullet$ & ※ & $\bullet$ & $\bullet$ & $\bullet$ & $\bullet$ \\
\hline Edward et al. [51], 2016 & $\bullet$ & $\Delta$ & $\bullet$ & $\bullet$ & $\bullet$ & * \\
\hline Vicky et al. [52], 2017 & * & $\Delta$ & $\Delta$ & $\bullet$ & $\Delta$ & $\bullet$ \\
\hline Julie [53], 2019 & $\bullet$ & $\Delta$ & $\bullet$ & $\bullet$ & * & $\bullet$ \\
\hline Shota Hamada et al. [54], 2019 & $\bullet$ & $\Delta$ & ※ & $\bullet$ & $\bullet$ & $\bullet$ \\
\hline Peter et al. [55], 2015 & $\bullet$ & $\bullet$ & ※ & $\bullet$ & $\Delta$ & $\Delta$ \\
\hline Maria et al. [56], 2017 & $\Delta$ & $\Delta$ & $\Delta$ & $\bullet$ & $\bullet$ & $\Delta$ \\
\hline Leena et al. [57], 2017 & $\bullet$ & $\Delta$ & $\bullet$ & $\bullet$ & * & $\bullet$ \\
\hline
\end{tabular}

Notes: $\bullet$ Low risk of bias; $\Delta$ High risk of bias; $*$ Unclear.

\section{Results}

\subsection{A Preliminary Review of the Relevant Literature}

It was found that three-quarters of the studies were made up of quantitative research, while qualitative research only accounted for one quarter. Moreover, the qualitative method was used in most research in China, while quantitative methods could be found in nearly every article in other countries, in which the acceptance by and understanding of the readers could be better. 
From the publication point of view, the journals that published the most related papers were BMC Health Services Research, Geriatrics \& Gerontology International, PLOS One, Public Health Nursing, Nursing Research (Chinese), and Chinese Health Economics (Chinese), respectively. Among them, BMC Health Service Research and PLOS One were tied at 15\% each, and Geriatrics $\mathcal{E}$ Gerontology International and Public Health Nursing each had 10\%. Besides, it was interesting that some of them were nursing and health, biology, physics, and other comprehensive journals, which are not pure medical journals.

\subsubsection{Classification by Country Studied}

The classification of articles published regarding the measurement of LTC (Long-Term Care) costs in different countries is presented in Figure 2.

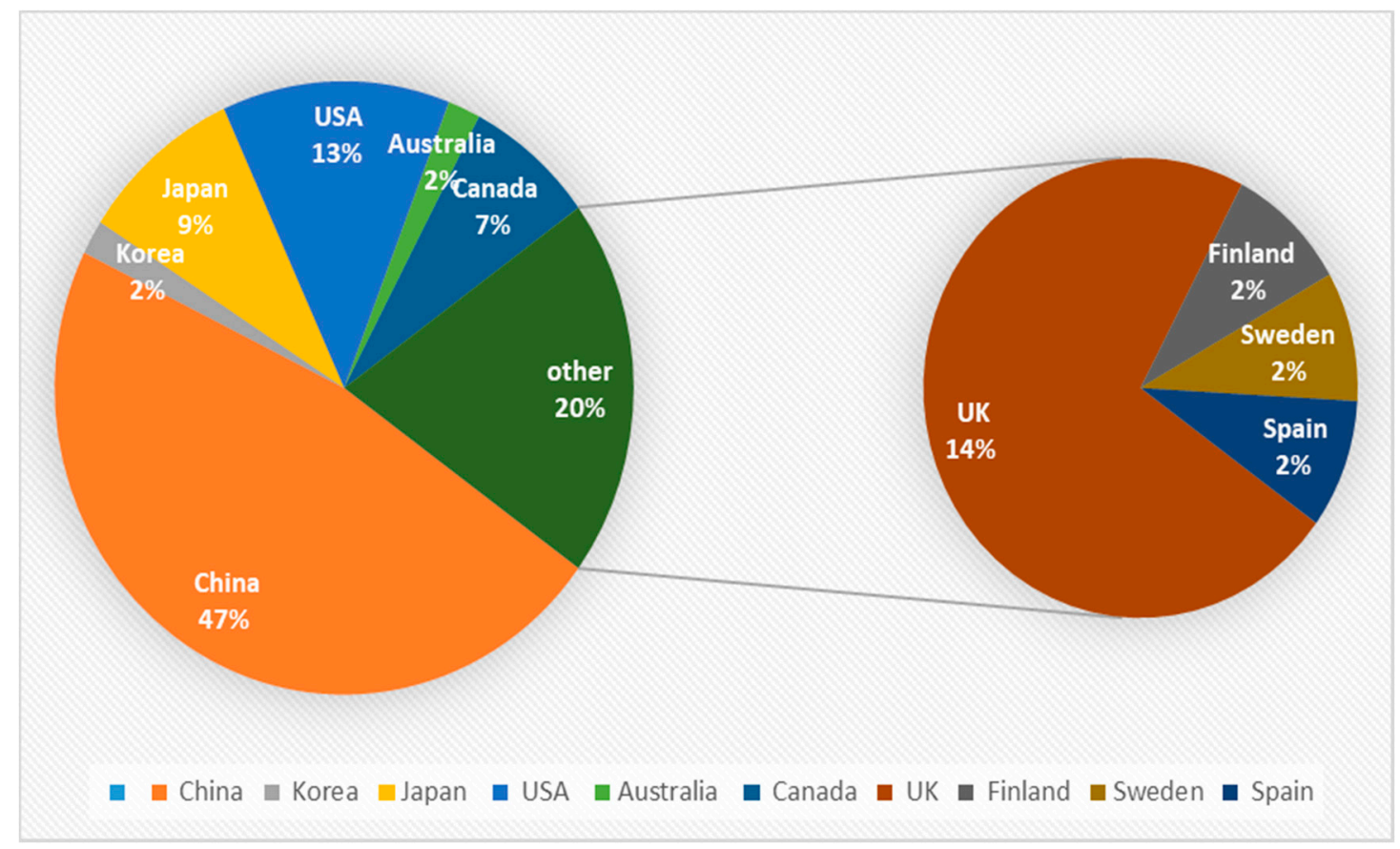

Figure 2. Classification of publication by country studied.

It can be seen from Figure 2 that the pie chart on the left is divided into eight parts according to the research object for LTC in related articles. It was clear that China has become the most popular research object, accounting for nearly half of all the published articles, and the study of LTC in the UK ranked the second. Meanwhile, the United States came in third place, accounting for $14 \%$ of the pie chart. It can be observed that there is a small circle on the right, composed of Spain, Sweden, Germany, and Finland.

\subsubsection{Classification by Publication Year}

The classification of articles published on LTC (Long-Term Care) costs across the timeline of the study (2010-2019) is presented in Figure 3. 


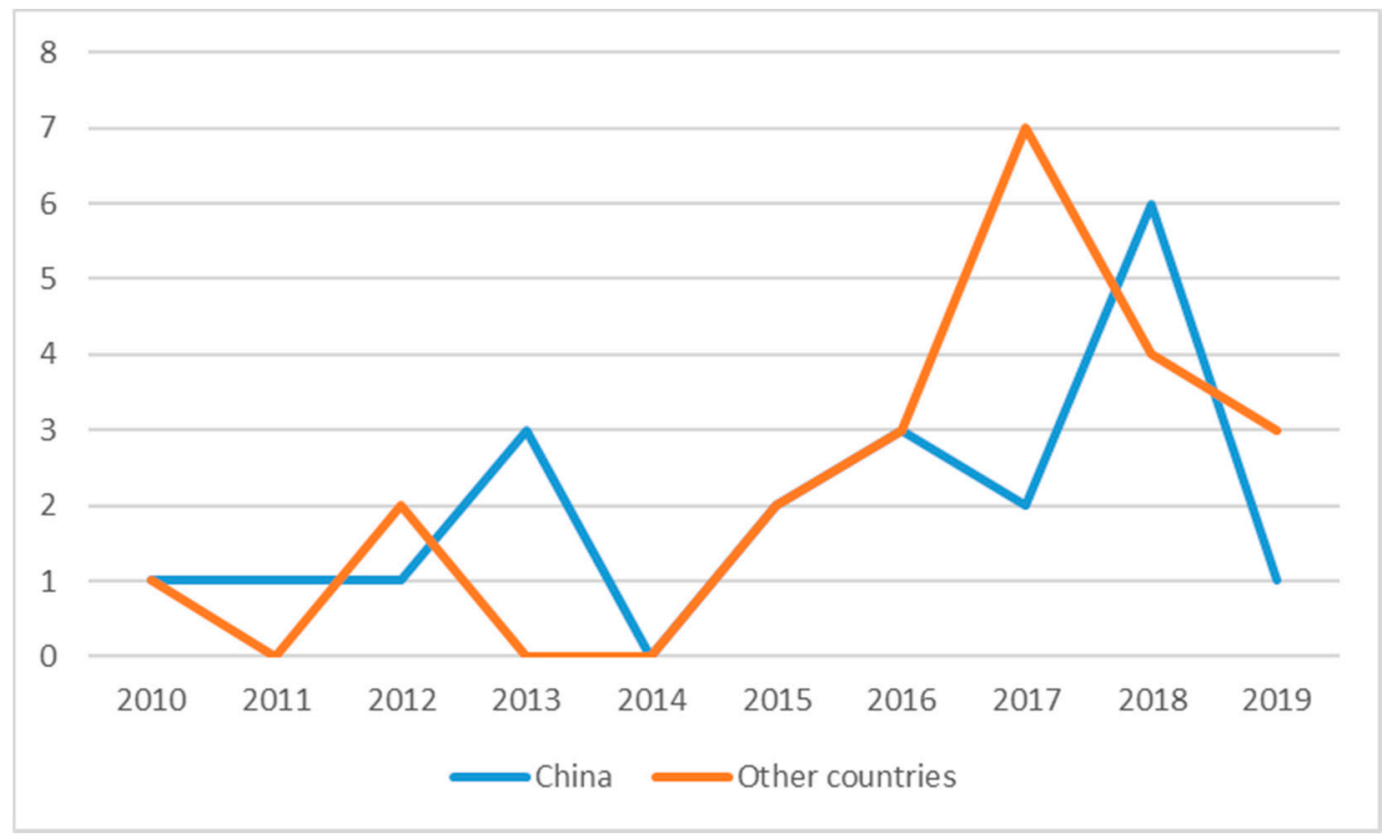

Figure 3. Classification of publication by year.

It can be seen from Figure 3 that the amount of research on LTC is not large in general and currently in a declining state, with peaks in 2017 and 2018. Nevertheless, it has shown a wavy upward trend. The attention of some scholars had been attracted to LTC since 2010. After a brief decline in 2014, it peaked in 2017 and 2018. Based on the analysis above, it can be inferred that more and more scholars at home and abroad have devoted themselves to the research of long-term care costs since 2014 and gradually achieved excellent results. The result could be attributed to the increasing emphasis on nursing in various countries. At the same time, it was reflected that the development of social structures in various countries is becoming more and more perfect.

\subsection{Measurement of Long-Term Care Costs in China}

In 2010, the cost accounting of home care programs was shown by Jin et al. [23], and the research into long-term care costs is getting more and more diversified (as shown in Table 2).

Table 2. Literature related to the measurement of Long-Term Care (LTC) costs in China.

\begin{tabular}{ccccc}
\hline Rank & Author, Date & Methodology & Sample & Key Conclusions \\
\hline 1 & Jin et al. [23], 2010 & $\begin{array}{c}\text { Semi-structured } \\
\text { interview }\end{array}$ & $\begin{array}{c}\text { Nine general service teams } \\
\text { of the Yin hang } \\
\text { community health service } \\
\text { center of Shanghai }\end{array}$ & $\begin{array}{c}\text { The government should increase } \\
\text { the price of home care services } \\
\text { and include it into medical } \\
\text { insurance to meet the cost } \\
\text { compensation of home care. }\end{array}$ \\
\hline 2 & Lu [24], 2013 & $\begin{array}{c}\text { Microsimulation } \\
\text { method }\end{array}$ & $\begin{array}{c}\text { The annual long-term care } \\
\text { social insurance payment } \\
\text { rate from 1995 to 2010 }\end{array}$ & $\begin{array}{c}\text { The long-term care security } \\
\text { system makes resources flow } \\
\text { from high-income groups to } \\
\text { low-income groups. }\end{array}$ \\
\hline Feng et al. [25], & ADL and IADL & $\begin{array}{c}\text { Community-dwelling } \\
\text { elderly in Shanghai, } \\
\text { 1998-2008 }\end{array}$ & $\begin{array}{c}\text { Demand for long-term care in } \\
\text { Shanghai led to a surge in } \\
\text { long-term care costs between } \\
\text { 1998 and 2008. }\end{array}$ \\
\hline
\end{tabular}


Table 2. Cont.

\begin{tabular}{|c|c|c|c|c|}
\hline Rank & Author, Date & Methodology & Sample & Key Conclusions \\
\hline 4 & Hu [26], 2015 & Markov model & $\begin{array}{l}\text { Data on disabled elderly } \\
\text { people in China }\end{array}$ & $\begin{array}{l}\text { Long-term care costs for the } \\
\text { elderly will soar in China in the } \\
\text { future. }\end{array}$ \\
\hline 5 & Yuan [27], 2018 & $\begin{array}{l}\text { Multiple logit } \\
\text { regression analysis }\end{array}$ & $\begin{array}{l}\text { Sample survey data of } \\
\text { disabled elders in the three } \\
\text { provinces of the northeast }\end{array}$ & $\begin{array}{l}\text { China should pay attention to } \\
\text { the financial pressure borne by } \\
\text { fund providers. }\end{array}$ \\
\hline 6 & $\begin{array}{l}\text { Liu and Zhong [28], } \\
2018\end{array}$ & Markov model & $\begin{array}{l}\text { CHARLS data for 2011, } \\
\text { 2013, and } 2015\end{array}$ & $\begin{array}{l}\text { It is imperative to establish a } \\
\text { national long-term care social } \\
\text { assistance system. }\end{array}$ \\
\hline 7 & Xu et al. [29], 2019 & $\begin{array}{l}\text { Bayesian quantile } \\
\text { regression }\end{array}$ & $\begin{array}{l}\text { The data of disabled } \\
\text { elderly people in China } \\
\text { from } 2003 \text { to } 2016\end{array}$ & $\begin{array}{l}\text { It is predicted long-term care } \\
\text { costs for each disability state of } \\
\text { the elderly in China will rise } \\
\text { sharply from } 2020 \text { to } 2050\end{array}$ \\
\hline 8 & $\begin{array}{c}\text { Fengyue and Junko } \\
{[30], 2018}\end{array}$ & Field investigation & $\begin{array}{l}\text { First-class nursing patients } \\
\text { in China }\end{array}$ & $\begin{array}{l}\text { Controlling labor costs and } \\
\text { reducing material costs are the } \\
\text { keys to reducing the LTC costs. }\end{array}$ \\
\hline 9 & Yu et al. [31], 2015 & Comparative Study & $\begin{array}{l}\text { Nursing project prices in } \\
\text { Chongqing } 2014 \text { and } \\
\text { Guangdong } 2006\end{array}$ & $\begin{array}{l}\text { It is suggested that the value of } \\
\text { nursing technical labor services } \\
\text { should be properly reflected } \\
\text { when formulating the price of } \\
\text { nursing projects. }\end{array}$ \\
\hline 10 & Fan et al. [32], 2016 & $\begin{array}{l}\text { Field survey and } \\
\text { expert consultation }\end{array}$ & $\begin{array}{l}\text { A primary care patient in a } \\
\text { tertiary hospital in } \\
\text { Chongqing from January } \\
\text { to March } 2013\end{array}$ & $\begin{array}{l}\text { LTC costs can be included in the } \\
\text { scope of medical insurance } \\
\text { reimbursement. }\end{array}$ \\
\hline 11 & Qun [33], 2013 & Comparative Study & $\begin{array}{l}\text { Top three elderly-hospitals } \\
\text { in Beijing (China) }\end{array}$ & $\begin{array}{l}\text { The adjustment of LTC service } \\
\text { prices has a long way to go. }\end{array}$ \\
\hline 12 & Li et al. [34], 2018 & $\begin{array}{l}\text { Essential thoughts } \\
\text { of RBVS }\end{array}$ & $\begin{array}{l}2012 \text { edition of the medical } \\
\text { service price item } \\
\text { specification work manual }\end{array}$ & $\begin{array}{l}\text { The constructed pricing model } \\
\text { of nursing service projects can } \\
\text { measure the value of LTC } \\
\text { services and fully reflect the } \\
\text { LTC costs. }\end{array}$ \\
\hline 13 & $\begin{array}{c}\text { Jin, Li, et al. [35], } \\
2018\end{array}$ & $\begin{array}{l}\text { Multiple linear } \\
\text { regression }\end{array}$ & $\begin{array}{l}42 \text { service items in } \\
\text { Shanghai }\end{array}$ & $\begin{array}{l}\text { Labor cost is a major factor in } \\
\text { the cost of long-term care } \\
\text { services. }\end{array}$ \\
\hline 14 & $\begin{array}{l}\text { Yang et al. [36], } \\
\quad 2016\end{array}$ & $\begin{array}{l}\text { A policy evaluation } \\
\text { of new models }\end{array}$ & $\begin{array}{l}51 \text { elderly of nursing } \\
\text { patients }\end{array}$ & $\begin{array}{l}\text { The total cost of institutional } \\
\text { care is far less than the cost of } \\
\text { general hospital inspections and } \\
\text { other routine expenses. }\end{array}$ \\
\hline 15 & Lu et al. [37], 2017 & $\begin{array}{l}\text { Multiple linear } \\
\text { regression }\end{array}$ & $\begin{array}{l}\text { Elderly chronic patients in } \\
\text { the urban area of Hefei }\end{array}$ & $\begin{array}{l}\text { Public long-term care policies in } \\
\text { China should focus on the } \\
\text { distinction between institutional } \\
\text { care and home care. }\end{array}$ \\
\hline 16 & $\begin{array}{l}\text { Huang et al. [38], } \\
2012\end{array}$ & $\begin{array}{l}\text { Multi-status } \\
\text { transition model }\end{array}$ & $\begin{array}{l}\text { Comparison of the costing } \\
\text { methods around the world } \\
\text { with Taiwan, China }\end{array}$ & $\begin{array}{l}\text { Through home care cost } \\
\text { accounting, the government can } \\
\text { provide information for the } \\
\text { government based on the family } \\
\text { cost data for the elderly with } \\
\text { different functional levels. }\end{array}$ \\
\hline 17 & $\begin{array}{l}\text { Song et al. [39], } \\
\quad 2016\end{array}$ & Comparative study & $\begin{array}{l}\text { Community and } \\
\text { institutional care survey } \\
\text { data }\end{array}$ & $\begin{array}{l}\text { To be cost-effective, community } \\
\text { care services should target } \\
\text { patients with a medium physical } \\
\text { disability. }\end{array}$ \\
\hline 18 & Fen et al. [40], 2017 & Logistic model & $\begin{array}{l}8500 \text { residents aged over } \\
60 \text { in Jiang Ning Road } \\
\text { were randomly selected } \\
\text { and observed in } 2014\end{array}$ & $\begin{array}{l}\text { Formal care provision in } \\
\text { Shanghai was not determined } \\
\text { by ADL scores but was instead } \\
\text { more related to income. }\end{array}$ \\
\hline
\end{tabular}


Most Chinese scholars estimated long-term care costs based on the degree of disability among the disabled elderly. For example, Lu [24], Feng et al. [25], Hu [26], and Yuan [27] calculated the basic LTC costs based on the Activities of Daily Life (ADL) classification of mild, moderate, and severe dysfunction. In addition, Liu and Zhong [28] compared the LTC costs generated by patients with different ADL function obstacles with the living allowances in urban and rural areas, which could be a new reference for the long-term care cost system. Xu et al. used the Bayesian quantile regression method to measure the high, medium, and low levels of long-term care cost prediction for each disability state of the elderly in China from 2020 to 2050 [29].

Other Chinese scholars focus on how to integrate the human value of nursing staff into the measurement system for long-term care costs, so as to achieve the goal of the scientific and reasonable measurement of long-term care costs. The value of nurses was noticed in the studies of Fengyue and Junko [30], Yu et al. [31], and Fan et al. [32], which discussed the LTC costs in Chongqing, Guangdong, and other provinces in China. Qun [33] compared the LTC costs in nine provinces of China with those in Texas, U.S. Li et al. constructed a pricing model for nursing service projects that can measure the value of LTC services and fully reflect the LTC costs [34]. With the development of the nursing industry, a variety of nursing services could be offered by nursing institutions, communities, and even in homes, aside from hospitals. The process of providing home care services in a community of Shanghai was discussed by Du et al. [35]. They calculated the cost of five plates, including manpower, materials, and another three big plates, and it was found that the current charge for the home care services could not cover the necessary expenditures.

The comparison of long-term care costs under different forms of care (such as institutional care, community care, and home care) has become another important topic of academic discussion regarding the development of elderly care institutions in China. Yang et al. [36] and Lu et al. [37] revealed that the total cost of institutional care is far less than the cost of general hospital inspections and other routine expenses. The direct and indirect costs of home care were calculated by Huang et al. [38] and Song et al. [39]. It can be concluded from their research that institutional care is suitable for patients whose daily life is marked by high dependence, while home or community care could be a better option for the less dependent. Then, a survey of the influencing factors for the utilization and cost of formal care in the elderly community of Shanghai was conducted by Fen et al. [40], who found that professional home care was more cost-effective compared with the care provided by family members.

In a word, LTC-related research is a relatively new concept in China. With the pilot practice of the LTCI system in Qingdao, Shanghai, Chongqing and other places, LTC-related research has begun to rise. However, due to the lack of official statistics and uniform standards of LTC costs, these studies have many difficulties, especially in empirical studies.

\subsection{Measurement of Long-Term Care Costs in Other Countries}

Developed countries such as those in Europe and the United States have paid attention to long-term care costs earlier, and the research objects were more diversified and comprehensive (as shown in Table 3). It was found by Ryan Greysen [41] that the LTC costs for the elderly with the highest level of functional disorders were $77 \%$ higher than for those without functional disorders. Lagergren et al. [42] predicted the future LTC costs in Japan and Sweden based on age, gender, and degree of ADL dysfunction. 
Table 3. Literature related to the measurement of LTC costs in other countries.

\begin{tabular}{|c|c|c|c|c|}
\hline Rank & Author, Date & Methodology & Sample & Key Conclusions \\
\hline 1 & $\begin{array}{c}\text { Ryan Greysen [41], } \\
2017\end{array}$ & $\begin{array}{l}\text { Generalized linear } \\
\text { model; gamma } \\
\text { regression model; } \\
\text { goodness-of-fit } \\
\text { analysis }\end{array}$ & $\begin{array}{c}\text { Create a } \\
\text { nationally-representative } \\
\text { sample of } 16,673 \text { Medicare } \\
\text { hospitalizations for } 8559 \\
\text { community-dwelling } \\
\text { seniors from } 2000 \text { to } 2012 \\
\text { using the Health and } \\
\text { Retirement Study (HRS). }\end{array}$ & $\begin{array}{l}\text { Functional impairment is } \\
\text { associated with increased } \\
\text { Medicare costs for post-acute } \\
\text { care and may be an unmeasured } \\
\text { but important marker of } \\
\text { long-term costs that cut across } \\
\text { conditions. }\end{array}$ \\
\hline 2 & $\begin{array}{l}\text { Lagergren et al. } \\
\text { [42], } 2018\end{array}$ & $\begin{array}{l}\text { Weighted } \\
\text { logarithmic, linear } \\
\text { regression }\end{array}$ & $\begin{array}{l}\text { Japanese data on LTC } \\
\text { assessments in nine } \\
\text { Japanese municipalities, } \\
\text { grouped. A corresponding } \\
\text { Swedish dataset from eight } \\
\text { varied municipalities was } \\
\text { collected in } 2002 \text { and } 2007 .\end{array}$ & $\begin{array}{l}\text { The sustainability of LTC } \\
\text { systems is a high priority in } \\
\text { Japan and Sweden, and better } \\
\text { decision support is needed to } \\
\text { guide policy in this area of the } \\
\text { welfare state. }\end{array}$ \\
\hline 3 & $\begin{array}{c}\text { Sharada et al. [43], } \\
2018\end{array}$ & $\begin{array}{l}\text { Logistic regression; } \\
\text { propensity score } \\
\text { matching }\end{array}$ & $\begin{array}{l}\text { Between } 1994 \text { and 2013, } \\
7271 \text { PD patients who met } \\
\text { study inclusion criteria } \\
\text { were identified in linked } \\
\text { CPRD-HES; } 7060 \text { were } \\
\text { matched with controls in } \\
\text { the United Kingdom (UK). }\end{array}$ & $\begin{array}{l}\text { Healthcare costs attributable to } \\
\text { PD increase in the year } \\
\text { following diagnosis and are } \\
\text { higher for patients with } \\
\text { indicators of advanced disease. }\end{array}$ \\
\hline 4 & $\begin{array}{l}\text { Larissa S et al. [44], } \\
2012\end{array}$ & $\begin{array}{l}\text { Wilcoxon test; the } \\
\text { generalized linear } \\
\text { model }\end{array}$ & $\begin{array}{l}\text { Claims data from the AOK } \\
\text { Bavaria Statutory Health } \\
\text { Insurance fund of } 9147 \\
\text { dementia patients in } 2006\end{array}$ & $\begin{array}{l}\text { Dementia poses a substantial } \\
\text { additional burden on the } \\
\text { German social security system, } \\
\text { and female dementia patients } \\
\text { need to be a key target group for } \\
\text { health services research in an } \\
\text { aging society. }\end{array}$ \\
\hline 5 & $\begin{array}{l}\text { Mitsuhiro S et al. } \\
\text { [45], } 2018\end{array}$ & $\begin{array}{l}\text { Multiple regression } \\
\text { analysis }\end{array}$ & $\begin{array}{l}\text { The Survey of Long-Term } \\
\text { Care Benefit Expenditures } \\
\text { in Japan }\end{array}$ & $\begin{array}{l}\text { The societal cost of dementia in } \\
\text { Japan appeared to be } \\
\text { considerable. Interventions to } \\
\text { mitigate this impact should be } \\
\text { considered }\end{array}$ \\
\hline 6 & $\begin{array}{l}\text { Hajime T et al. [46], } \\
2019\end{array}$ & $\begin{array}{l}\text { Cross-section } \\
\text { analysis on time } \\
\text { series }\end{array}$ & $\begin{array}{c}169 \text { patients with } \\
\text { Alzheimer's disease or } \\
\text { mild cognitive impairment } \\
\text { in Japan }\end{array}$ & $\begin{array}{l}\text { As the number of patients with } \\
\text { Alzheimer's disease increases, } \\
\text { direct social costs will increase. }\end{array}$ \\
\hline 7 & $\begin{array}{l}\text { Greg A et al. [47], } \\
2015\end{array}$ & $\begin{array}{l}\text { Polynomial } \\
\text { regression model }\end{array}$ & $\begin{array}{l}3811 \text { veterans hospitalized } \\
\text { for ischemic stroke in } \\
\text { Veterans Health } \\
\text { Administration facilities in } \\
2007\end{array}$ & $\begin{array}{l}\text { Care trajectories after stroke } \\
\text { were associated with stroke } \\
\text { severity and functional } \\
\text { dependency and then } \\
\text { had a dramatic impact on } \\
\text { subsequent costs. }\end{array}$ \\
\hline 8 & $\begin{array}{l}\text { Ramon L et al. [48], } \\
2018\end{array}$ & $\begin{array}{l}\text { Multiple regression } \\
\text { model }\end{array}$ & $\begin{array}{l}\text { All patients with first-ever } \\
\text { incident ACLVI from } 2002 \\
\text { to } 2012\end{array}$ & $\begin{array}{c}\text { Hospital care costs were } \\
\text { significantly higher than for } \\
\text { stroke over the long term and } \\
\text { were similar after the inclusion } \\
\text { of the costs of } \\
\text { institutionalization. }\end{array}$ \\
\hline 9 & $\begin{array}{l}\text { Julieta et al. [49], } \\
2016\end{array}$ & $\begin{array}{l}\text { Kaplan-Meier } \\
\text { method }\end{array}$ & $\begin{array}{l}699 \text { patients diagnosed } \\
\text { and treated for CRC in } \\
\text { 2000-2006 (Spanish, } \\
\text { Barcelona). }\end{array}$ & $\begin{array}{l}\text { This study is the first to provide } \\
\text { long-term cost estimates for } \\
\text { CRC treatment, by stage at } \\
\text { diagnosis and phase of care, } \\
\text { based on data from clinical } \\
\text { practice in Spain. }\end{array}$ \\
\hline 10 & $\begin{array}{l}\text { Saori et al. [50], } \\
\quad 2017\end{array}$ & $\begin{array}{l}\text { Questionnaire } \\
\text { survey }\end{array}$ & $\begin{array}{c}\text { Facilities affiliated with the } \\
\text { Kyoto Prefecture }\end{array}$ & $\begin{array}{l}\text { The cost of preparing the PPE } \\
\text { needed for the preventive } \\
\text { measures varied among the } \\
\text { facilities. }\end{array}$ \\
\hline
\end{tabular}


Table 3. Cont.

\begin{tabular}{|c|c|c|c|c|}
\hline Rank & Author, Date & Methodology & Sample & Key Conclusions \\
\hline 13 & Julie [53], 2019 & ABF model & $\begin{array}{l}\text { All patients who had } \\
\text { received primary bariatric } \\
\text { surgery in a Tasmanian } \\
\text { public hospital }\end{array}$ & $\begin{array}{c}\text { At three years postoperatively } \\
\text { versus preoperatively, episodes } \\
\text { of care and costs reduced } \\
\text { substantially, particularly for } \\
\text { people with } \\
\text { diabetes/cardiovascular disease. }\end{array}$ \\
\hline 14 & $\begin{array}{l}\text { Shota Hamada et al. } \\
\text { [54], } 2019\end{array}$ & $\begin{array}{l}\text { Generalized linear } \\
\text { regression models }\end{array}$ & $\begin{array}{l}1324 \text { residents who were } \\
\text { admitted in } 2015 \text { in Japan }\end{array}$ & $\begin{array}{l}\text { There was no apparent } \\
\text { association between the level of } \\
\text { long-term care needs and drug } \\
\text { costs. }\end{array}$ \\
\hline 15 & $\begin{array}{l}\text { Peter et al. [55], } \\
\qquad 2015\end{array}$ & Double tail test & Ontario, Canada & $\begin{array}{l}\text { This analysis adds new } \\
\text { information about the breadth } \\
\text { of end-of-life healthcare, which } \\
\text { consumes a large proportion of } \\
\text { Ontario's healthcare budget. }\end{array}$ \\
\hline 16 & $\begin{array}{l}\text { Maria et al. [56], } \\
\qquad 2017\end{array}$ & Time-series design & $\begin{array}{l}\text { The elderly aged } 65 \text { years } \\
\text { and above of } 28 \text { European } \\
\text { countries from } 2004 \text { to } 2015\end{array}$ & $\begin{array}{l}\text { Demographic, societal, and } \\
\text { health changes could } \\
\text { considerably affect LTC needs } \\
\text { and services, resulting in higher } \\
\text { LTC related costs. }\end{array}$ \\
\hline
\end{tabular}

As the research on long-term care is more and more in-depth and comprehensive, the research on long-term care costs was more detailed regarding the post-care costs of specific diseases. Some studies on the LTC costs of Parkinson's disease [43-45], Alzheimer's disease [46-48], colorectal cancer [49], and viral gastroenteritis [50] were conducted. In addition to cancer, which has been a problem for a long time, even research on the LTC costs of alcoholism was carried out by Edward et al. [51]. Overweightness is a public health problem all over the world, and obesity has become a common disease. Thus, Vicky et al. [52] calculated the differences in LTC costs associated with BMI in UK and found that the larger the body mass index, the higher the related costs were. Julie [53] discovered that the cost of care could be decreased after bariatric surgery in Australia. Besides, the LTC cost might be affected by the payment policies of the government, which has been proved by the work of Shota Hamada et al. [54].

Comparisons of long-term care costs under different forms of care, such as institutional care and home care, are also a focus of research in developed countries. Peter et al. [55] compared the LTC costs for high-income people with those for the farmers in institutional care and proved that the LTC cost for farmers was much less. In order to explore whether the increase in the elderly population will make long-term care costs rise, the trajectory of long-term care in 28 European countries was explored by Maria et al. [56], and it was found that the cost reduced as the expenditure of the government on health services was increased. At the same time, the elderly over 65 had turned to home care, which reflects the cost-effectiveness of home care to some extent. Leena et al. [57] studied the cost of all-day use on long-term care from 2002 to 2013 in Finland, and it was discovered that the cost in the shelters is much lower than that in nursing institutions. 


\section{Discussion}

With the acceleration of the population aging process in most countries, long-term care has gradually been accepted by the global community. After more than 20 years of research and practice, developed countries have generally recognized that the long-term care service system should be effectively separated from the medical system, and a relatively independent long-term care service system should be established. At the same time, developed countries, especially Germany, Japan, and the United States, have initially established long-term care service systems supported by public long-term care insurance system as the main body, and service standards and norms, supplemented by the active participation of family members, social workers, and volunteers. In view of the rapidly aging society in China, it is imperative to actively explore the establishment of an independent long-term care service system. However, China's social pension and nursing function mechanism has not been paid enough attention to and developed well, especially in the sense that medical insurance does not pay long-term nursing expenses. As a result, high nursing expenses are unbearable for ordinary families. Therefore, our review systematically searched the articles on the measurement of long-term care costs from 2010 to 2019, and compared China with other countries, hoping to further expand the academic space for the study of long-term care costs in China in the future and to provide an important policy basis for the government to build a sustainable long-term care service system.

In 2010, cost accounting for home care programs was shown by a study published in the Nursing Journal of the Chinese People's Liberation Army [23], and research into long-term care costs is getting more and more diversified. Until 2017 and 2018, the peak number of articles had been published so far, which means that the study of long-term care costs is gradually becoming more and more acceptable. It is acknowledged that, at the same time, academic circles at home and abroad are also quietly changing. Besides, it can be observed that qualitative research methods are applied in most studies in China, while studies around the world mainly use quantitative research methods, and the number of related articles around the world has exceeded those in China. It is believed that much related research on long-term care in various countries will appear in well-known journals at home and abroad in the future. The research objects are more extensive, and the content is more detailed. The establishment of long-term care systems in various countries is no longer empty talk.

In terms of specific research content or research perspectives, China and other countries show some similarities and differences.

Firstly, most Chinese scholars estimated long-term care costs based on the degree of disability among the disabled elderly [24-27]. Moreover, Xu et al. used the Bayesian quantile regression method to measure the high, medium, and low levels of long-term care cost prediction for each disability state of the elderly in China from 2020 to 2050 [28], which could be a new reference for the long-term care cost system. On the other hand, there are also a large number of relevant studies based on the degree of ADL dysfunction in European and American countries [41,42]. In fact, studies on long-term care costs in European and American countries were carried out earlier. For example, Martin [58] predicted the future costs for long-term care costs in the United Kingdom, with analysis also based on the degree of disability. It can be seen that both the studies in China and in other countries estimated long-term care costs based on the degrees of disability among the disabled elderly, which implies that the accurate prediction of the scale of disabled and semi-disabled elderly will be important in the measurement of long-term care costs in China in the future.

Secondly, both China's and other countries' scholars are starting to pay attention to how to integrate the human value of nursing staff into the measurement system for long-term care costs, so as to achieve the goal of the scientific and reasonable measurement of long-term care costs [30-32]. However, the studies of European and American countries are more and more in-depth and comprehensive, and more detailed regarding the post-care cost of specific diseases, such as Parkinson's disease [43-45], Alzheimer's disease [46-48], colorectal cancer [49], and viral gastroenteritis [50].

Thirdly, the long-term care costs under different forms of care (such as institutional care, community care, and home care) have become another important topic of academic discussion regarding the 
development of elderly care institutions in China [36-40] and other countries [55-57]. By comparison, the relevant research in China is still a simple analysis of the comparison of long-term care costs under different forms of care, but the relevant research in other countries has begun to delve into the expectations and comparison of long-term care costs of different forms of care among patient groups with different income or education levels [55].

In conclusion, the scientific measurement of long-term care costs is an important basis for the government to formulate a long-term care policy in response to the aging population. Through the comparison between China and other countries in this review, we found that the measurement of LTC costs is more and more refined, which is mainly reflected in two aspects: the comparison of LTC costs after discharge for different chronic diseases, and the comparison of LTC costs for different nursing methods. This also provides us with the countermeasures to solve this problem in the future. Firstly, the accurate prediction of the scale of disabled and semi-disabled elderly is important for the measurement of long-term care costs in China in the future. Secondly, the human value of long-term care providers should be taken into account, and the differences of long-term care costs due for different chronic diseases should be further studied. Moreover, the comparison of long-term care costs based on different care methods (institutional care, home care, or community care) is also an important basis for policymaking. Facing increasing long-term care costs, fund-raising has become a key aspect in the construction of the long-term care service system. According to the experience of the USA, Sweden, and other countries, in the long run, public long-term care insurance (LTCI) separated from medical insurance may not be enough to fully cope with the surging long-term care costs [59]. Therefore, introducing social capital, developing private long-term care insurance (LTCI) in the private market, and realizing the effective complementarity between private long-term care insurance (LTCI) and public long-term care insurance (LTCI) may be an effective pathway [60].

At present, to cope with the increasing cost of LTC, some countries have implemented and gradually improved LTCI systems, which can be divided into two types. The first is the Nordic "welfare state" model of comprehensive public welfare, which is obviously not suitable for China's specific national conditions. The second is the "corporatist-welfare" model, which emphasizes the equivalence of LTCI rights and obligations and is more in line with China's current national conditions [12]. Firstly, publicly providing LTC to all of its citizens without regard to the individual need for public assistance is the basis of the LTC system in Sweden. However, it is an extremely expensive system that is fraught with the potential for abuse [19]. Secondly, home care may be cheaper than institutional care. For instance, Sweden and some OECD countries in Europe focus on providing home care versus institutional care. However, LTC public funding was almost exclusively provided in institutions due to the vast majority of LTC being provided by family and friends in USA. This is similar to in China, where most of the LTC now consists of home care and community care. In addition, how to allocate the value of LTC services, such as the manpower value of service providers, is also an important consideration in the future development of the LTC system in China.

\section{Conclusions}

This review includes 20 Chinese articles and 22 articles from other countries. Through comparison, this review draws some valuable conclusions for future academic research and policymaking. In future academic research, we should fully consider the human value of long-term care providers and further study the differences in long-term care costs due to different chronic diseases. This review was limited by the amount of current research on this topic, the search strategy utilized, the number of databases searched, and researchers' and publication bias that may have affected the value and accessibility of the research recognized. We will continue to improve in future research.

Author Contributions: Conceptualization, X.X.; methodology, L.Z.; software, X.X.; formal analysis, Q.Z.; investigation, Q.W.; resources, L.Z; data curation, L.Z.; writing-original draft preparation, Q.Z; writing-review and editing, X.X.; visualization, X.X.; supervision, W.F.; project administration, Q.Z.; funding acquisition, Q.Z. All authors have read and agree to the published version of the manuscript. 
Funding: This research was funded by the MOE Project of Key Research Institute of Humanities and Social Sciences of Research Center for Economy of Upper Reaches of the Yangtse River "Commercial circulation team funding project", grant number No: CJSYTD201701, China Chongqing Education Commission Humanities and Social Sciences Research Project, grant number No: 19SKGH089, and Open subject of Collaborative Innovation Center for Urban Industries Development in Chengdu-Chongqing Economic Zone, grant number No: KFJJ2019029.

Acknowledgments: We thank Timothy Kyng and Fei Guo at Macquarie University for their thoughtful guidance.

Conflicts of Interest: The authors declare no conflict of interest.

\section{References}

1. Department of Economic and Social Affairs of United Nations. World Population Prospects (WPP2019). 2019. Available online: https://www.un.org/development/desa/zh/news/population/world-population-prospects2019.html (accessed on 5 January 2020).

2. National Bureau of Statistics of China. China Statistical Yearbook 2019. Available online: http://www.stats. gov.cn/tjsj/ndsj/2019/indexch.htm (accessed on 20 January 2020).

3. Xu, X.; Chen, L. Influencing factors of disability among the elderly in China, 2003-2016: Application of Bayesian quantile regression. J. Med. Econ. 2019, 22, 605-611. [CrossRef] [PubMed]

4. Xu, X.; Xu, Z.; Chen, L.; Li, C. How Does Industrial Waste Gas Emission Affect Health Care Expenditure in Different Regions of China: An Application of Bayesian Quantile Regression. Int. J. Environ. Res. Public Health 2019, 16, 2748. [CrossRef] [PubMed]

5. Chen, L.; Zhuo, Y.; Xu, Z.; Xu, X.; Gao, X. Is Carbon Dioxide (CO2) Emission an Important Factor Affecting Healthcare Expenditure? Evidence from China, 2005-2016. Int. J. Environ. Res. Public Health 2019, 16, 3995. [CrossRef] [PubMed]

6. Huang, X.; Xu, X.; Wang, Q.; Zhang, L.; Gao, X.; Chen, L. Assessment of Agricultural Carbon Emissions and Their Spatiotemporal Changes in China, 1997-2016. Int. J. Environ. Res. Public Health 2019, 16, 3105. [CrossRef]

7. Xu, X.; Huang, X.; Huang, J.; Gao, X.; Chen, L. Spatial-Temporal Characteristics of Agriculture Green Total Factor Productivity in China, 1998-2016: Based on More Sophisticated Calculations of Carbon Emissions. Int. J. Environ. Res. Public Health 2019, 16, 3932. [CrossRef]

8. Xu, X.; Huang, X.; Zhang, X.; Chen, L. Family Economic Burden of Elderly Chronic Diseases: Evidence from China. Healthcare 2019, 7, 99. [CrossRef]

9. Zeng, L.; Xu, X.; Zhang, C.; Chen, L. Factors Influencing Long-Term Care Service Needs among the Elderly Based on the Latest Anderson Model: A Case Study from the Middle and Upper Reaches of the Yangtze River. Healthcare 2019, 7, 157. [CrossRef]

10. WHO. Home-Based and Long-Term Care, Report of a WHO Study Group; WHO Technical Report Series 898; World Health Organization: Geneva, Switzerland, 2000.

11. The National Institute on Aging (NIA). Available online: https://www.nia.nih.gov/health/what-long-termcare (accessed on 11 April 2020).

12. Wei-dong, D. Long Term Care Insurance: A Rational Choice of Old-age Security in China. Popul. J. 2016, 2, 72-81. (In Chinese)

13. Robinson, R.; Dixon, A. United Kingdom Health Care Systems in Transition; European Observatory on Health Care Systems: Copenhagen, Denmark, 1999.

14. Campbell, J.C.; Ikegami, N. Long-term insurance comes to Japan. Health Aff. 2000, 19, 26-39. [CrossRef]

15. Hiraoka, K. Long-Term Care Insurance and Welfare Mix in Japan; Ochanomizu Joshi Daigaku Jinbunkagaku Kiyo, Ochanomizu University: Tokyo, Japan, 2001; Volume 54, pp. 133-147.

16. Tsutsui, T.; Muramatsu, N. Care needs certification in the long-term care insurance system of Japan. J. Am. Geriatr. Soc. 2005, 53, 522-527. [CrossRef]

17. Lagergren, M. The systems of care for frail elderly persons: The case of Sweden. Aging Clin. Exp. Res. 2002, 14, 252-257. [CrossRef] [PubMed]

18. Chen, L.; Zhang, X.; Xu, X. Health Insurance and Long-Term Care Services for the Disabled Elderly in China: Based on CHARLS Data. Risk Manag. Healthc. Policy 2020, 13, 155-162. [CrossRef] [PubMed] 
19. Paul, D.D.S., III; David, P.; Schaeffer, K.C. Long-term care policy: What the United States can learn from Denmark, Sweden, and the Netherlands. In Proceedings of the Business \& Health Administration Proceedings, Chicago, IL, USA, 22-24 March 2017; pp. 223-236.

20. Freundlich, N. Long-Term Care: What Are the Issues? Robert Wood Johnson Foundation. 2014. Available online: http://www.rwjf.org/content/dam/farm/reports/issue_briefs/2014/rwjf410654 (accessed on 18 September 2016).

21. Moher, D.; Liberati, A.; Tetzlaff, J.; Altman, D.G.; The PRISMA Group. Preferred Reporting Items for Systematic Reviews and Meta-Analyses: The PRISMA Statement. PLoS Med. 2009, 6, e1000097. [CrossRef]

22. Kim, S.Y.; Park, J.E.; Lee, Y.J.; Seo, H.J.; Sheen, S.S.; Hahn, S.; Jang, B.H.; Son, H.J. Testing a tool for assessing the risk of bias for nonrandomized studies showed moderate reliability and promising validity. J. Clin. Epidemiol. 2013, 66, 408-414. [CrossRef]

23. Liu, J.; Lu, W.; Xu, Q.; Wang, Z. Cost accounting of home care items in community health service centers. Nurs. J. Chin. People's Lib. Army 2010, 27, 736-738. (In Chinese)

24. Chen, L. Financial support and fair guarantee of long-term care costs in China. Financ. Res. 2013, 39, 73-85. (In Chinese)

25. Feng, Q.; Zhen, Z.; Purser, J. Trends in ADL and IADL disability in community-dwelling older adults in Shanghai, China, 1998-2008. J. Gerontol. B Psychol. Sci. Soc. Sci. 2013, 68, 476-485. [CrossRef]

26. Hong-wei, H. Demand assessment and forecast of China's elderly Long-Term Care services. China Popul. Sci. 2015, 3, 79-89. (In Chinese)

27. Li, Y. Calculation and analysis of the scale of long-term care funds for disabled elders in China. Popul. J. 2018, 40, 78-85. (In Chinese)

28. Liu, X.; Zhong, R. Estimation of the cost of social assistance for the elderly in the "dual hardship" of Chinese cities. J. Anhui Norm. Univ. (Hum. Soc. Sci.) 2018, 46, 97-106. (In Chinese)

29. Xu, X.; Chen, L. Projection of Long-Term Care Costs in China, 2020-2050: Based on the Bayesian Quantile Regression Method. Sustainability 2019, 11, 3530. [CrossRef]

30. Fengyue, L.; Junko, O. Financing elderly people's long-term care needs: Evidence from China. Int. J. Health Plan. Manag. 2018, 33, 479-488. [CrossRef]

31. Yu, X.; Deng, A.; Hu, Y.; Wu, C.; Qiu, J.; Guo, W. Comparative analysis of the price of nursing items between Chongqing's medical service price specification (2014 version) and Guangdong's current medical service price specification. Chin. Health Econ. 2015, 34, 50-53. (In Chinese)

32. Zeng, F.; Ye, H.; Luo, Y. Cost accounting of primary care in the surgical system of a tertiary hospital in Chongqing. Chongqing Med. 2016, 45, 2156-2157. (In Chinese)

33. Zhang, Q.; Yao, H.; Chen, Y. Necessity of price adjustment of comprehensive medical service items in China from the perspective of low nursing fees. China Health Econ. 2013, 32, 20-22. (In Chinese)

34. Li, L.; Song, Z.; Zheng, S. Research on pricing model of nursing service items based on health economics and RBRVS. Nurs. Res. 2018, 32, 55-59. (In Chinese)

35. Du, L.; Feng, L.; Peng, Y.; Wang, C.; Xie, C.; Chen, D.; Cao, Y.; Ding, H. Cost accounting and analysis of influencing factors for long-term care services in Shanghai. Chin. Health Econ. 2018, 37, 41-44. (In Chinese)

36. Yang, W.; He, J.; Mossialos, E. Financing institutional long-term care for the elderly in China: A policy evaluation of new models. Health Policy Plan. 2016, 31, 1391-1401. [CrossRef]

37. Lu, B.; Liu, X.; Yang, M. A budget proposal for China's public long-term care policy. J. Aging Soc. Policy 2017, 29, 84-103. [CrossRef]

38. Huang, F.; Wu, C. A study of long-term care demand of the elderly in China: Based on multi-status transition model. Econ. Res. J. 2012, 2, 119-130.

39. Song, B.; Sun, Q.; Li, Y.; Que, C. Evaluating the Sustainability of Community-Based Long-Term Care Programmes: A Hybrid Multi-Criteria Decision Making Approach. Sustainability 2016, 8, 657. [CrossRef]

40. Li, F.; Fang, X.; Gao, J.; Ding, H.; Wang, C.; Xie, C.; Yang, Y.; Jin, C. Determinants of formal care use and expenses among in-home elderly in Jing'an district, Shanghai, China. PLoS ONE 2017, 12, e0176548. [CrossRef]

41. Ryan, G.S.; Irena, S.W.; John, B.; Kenneth, E.C. Functional Impairment: An unmeasured marker of post-acute Medicare costs in seniors. HHS Public Access 2017, 65, 1996-2002.

42. Marten, L.; Noriko, K.; Yasuhiko, S. Future Costs of Long-term Care in Japan and Sweden. Int. J. Health Serv. 2018, 48, 128-147. 
43. Sharada, W.; Mihail, S.; Tzu-Chun, K.; Travis, S.T.; Silke, W.; Rod, S.T.; Anette, S. Short- and long-term cost and utilization of health care resources in Parkinson's disease in the UK. Mov. Disord. 2018, 33, 974-981.

44. Larissa, S.; Petra, M.; Reiner, L.; Sonja, W.; Hilmar, M.; Peter, M.; Elmar, G.; Rolf, H. Excess costs of dementia disorders and the role of age and gender-An analysis of German health and Long-term care cost claims data. BMC Health Serv. Res. 2012, 12, 165.

45. Mitsuhiro, S.; Akira, N.; Ryo, S.; Baku, I.; Toshiaki, B.; Kimio, Y.; Masaru, M. The estimated cost of dementia in Japan, the most aged society in the world. PLOS ONE 2018, 13, e0206508.

46. Hajime, T.; Atsuko, K.; Akira, K.; Shinji, M. Increase in direct social care costs of Alzheimer's disease in Japan depending on dementia severity. Geriatr. Gerontol. Int. 2019, 19, 1023-1029.

47. Greg, A.; Susan, O.; Mathew, J.R.; Laura, J.M.; Linda, S.W.; Joanne, K.D.; Michael, S.P.; Neale, C. Care Trajectories of Veterans in the 12 Months After Hospitalization for Acute Ischemic Stroke. Circ. Cardiovasc. Qual. Outcomes 2015, 8, 131-140.

48. Ramon, L.; Dominic, P.J.H.; Kathleen, G.N.; Emily, D.; Peter, M.R. Hospital and Institutionalization Care Costs after Limb and Visceral Ischemia Benchmarked Against Stroke: Long-Term Results of a Population Based Cohort Study. Eur. J. Vasc. Endovasc. 2018, 56, 271-281.

49. Julieta, C.; Xavier, C.; Eduard, M.; Pietro, C.; Josep, M.; Francesc, C. Long-term costs of colorectal cancer treatment in Spain. BMC Health Serv. Res. 2016, 16, 56.

50. Saori, F.; Tatsuro, I.; Takeo, N. Variations in status of preparation of personal protective equipment for preventing norovirus gastroenteritis in long-term care facilities for the elderly. J. Eval. Clin. Pract. 2017, 23, 1203-1210.

51. Edward CF, W.; George, S.; Zulfiquar, M. The Long-Term Cost to the UK NHS and Social Services of Different Durations of IV Thiamine (Vitamin B1) for Chronic Alcohol Misusers with Symptoms of Wernicke's Encephalopathy Presenting at the Emergency Department. Appl. Health Econ. Health Policy 2016, 14, 205-215.

52. Vicky, R.C.; Nick, C.; Jane, W.; Richard, F.; Harry, R. Estimating the variation in need for community-based social care by body mass index in England and associated cost: Population-based cross-sectional study. BMC Public Health 2017, 17, 667.

53. Julie, A.C.; Martin, H.; Daniel, D.; Matthew, G.; Barry, H.; Ian, J.; Alison, V.; Alexandr, K.; Amanda, N.; Stephen, W.; et al. Long-Term Inpatient Hospital Utilization and Costs (2007-2008 to 2015-2016) for Publicly Waitlisted Bariatric Surgery Patients in an Australian Public Hospital System Based on Australia's Activity-Based Funding Model. Pharm. Econ. 2019, 3, 599-618.

54. Shota, H.; Taro, K.; Nobuo, S.; Shinya, I.; Nanako, T.; Jiro, O.; Masahiro, A. Drug costs in long-term care facilities under a per diem bundled payment scheme in Japan. Geriatr. Gerontol. Int. 2019, 19, 667-672.

55. Peter, T.; Walter, P.W.R.; Peter, W.; Yu, Q.; Bai, S.; Bronskill, D. The Health Care Cost of Dying: A Population Based Retrospective Cohort Study of the Last Year of Life in Ontario, Canada. PLoS ONE 2015, 10, e0121759.

56. Maria, M.; Jacopo, L.; Maria, M.; Marco, B.; Maria, P.; Walter, R.; Gianfranco, D. Trajectories of long-term care in 28 EU countries:evidence from a time series analysis. Eur. J. Public Health 2017, 27, 948-954.

57. Leena, F.; Marja, J.; Jutta, P.; Mari, A.; Jani, R.; Pekka, R. Trends in the use and costs of round-the-clock long-term care in the last two years of life among old people between 2002 and 2013 in Finland. BMC Health Serv. Res. 2017, 17, 668.

58. Martin, K.; Les, M.; Ben, R. Future costs for long-term care cost projections for long-term care for older people in the United Kingdom. Health Policy 2006, 75, 187-213.

59. Kim, H.; Jung, Y.I.; Kwon, S. Delivery of institutional long-term care under two social insurances: Lessons from the Korean experience. Health Policy 2015, 119, 1330-1337. [CrossRef]

60. Lin, H.; Prince, J. The impact of the partnership long-term care insurance program on private coverage. J. Health Econ. 2013, 32, 1205-1213. [CrossRef]

(C) 2020 by the authors. Licensee MDPI, Basel, Switzerland. This article is an open access article distributed under the terms and conditions of the Creative Commons Attribution (CC BY) license (http://creativecommons.org/licenses/by/4.0/). 